\title{
MANAGEMENT OF NIDRANASHA A CASE REPORT
}

\section{SHIDDNAGOUDA KB ${ }^{1 *}$ AND KB ROY}

1: PhD Scholar Department of Kayachikitsa Parul University, Parul Institute of Ayurved, Limda, Vadodara, 391760 Gujarat, India

2: Proffessor \& HOD Department of Kayachikitsa, Parul University, Parul Institute of Ayurved, Limda, Vadodara 391760, Gujarat, India

*Corresponding Author: Siddanagoud KB: E Mail: siddanagouda88@gmail.com Received 12 ${ }^{\text {th }}$ Dec. 2021; Revised 14 ${ }^{\text {th }}$ Jan. 2022; Accepted $7^{\text {th }}$ Feb. 2022; Available online $5^{\text {th }}$ March 2022 https://doi.org/10.31032/IJBPAS/2022/11.3.1049

\begin{abstract}
Acoording to Ayurvedic classical text Nidra (Sleep) is considered as one among the Trayoupasthambha ${ }^{1}$ i.e. one among the three pillars of life, because good and sound sleep gives good health otherwise it leads to the ill health, not only this nidra even responsible for proper learning, immune system of our body. If Nidra is suppressed for prolong time it produces certain ill effect on the body the most common presentation of Nidranasha are Shirashoola, Angamarda, Angasada, Ajeerna, Jrimba, Klama, Glani, Vibhanda etc. At present scenario of clinical practice around $9 \%$ of general population suffering from Nidranasha (Insomnia) the available treatment for Insomnia in contemporary medicine is Benzodiazepines, the most common side effects Benzodiazepines is drowsiness, Light-headedness, Confusion, Unsteadiness, dizziness, Slurred speech, muscle weakness, memory problems. To prevent all these side effects and to induce good sleep ayurveda is having different Panchakarma treatment and oral medication in the form of shodhana and shamana. Hence here a case of Nidranasha is successfully treated with panchakarma and Shamana medicine.
\end{abstract}

Keywords: Nidra, Nidranasha, Shodana, Shamana,I nsomnia, Benzodiazepines

\section{INTRODUCTION}

Sleep is a naturally recurring state of mind and body, characterized by inhibition of nearly all voluntary altered consciousness, relatively inhibited muscles during rapid eye movement (REM) 
sleep, and reduced interactions with surroundings $^{2}$. It is distinguished from wakefulness by a decreased ability to react to stimuli, but more reactive than a coma or disorders of consciousness, with sleep displaying different, active brain patterns. Even Ayurveda also says Nidra is defined as when Manas (Mind) become exhausted their will be lack of perception of knowledge of Indriyas that state is called as Nidra/Swapna ${ }^{3}$. Duration and requirement of sleep depends on age and individual, on an average human beings spent $1 / 3^{\text {rd }}$ of our life in sleep. So for the maintenance since of good health one needs to follow the good code and conducts.

\section{CASE STUDY-PRADHANA VEDANA:}

Reduced sleep since 6months associated with headache, giddiness, indigestion and generalized body ache.
BRIEF HISTORY: A 65 years male patient not a K/C/O DM/HTN was apparently normal 6months back. When he came to our hospital Kayachikitsa OPD (OPD No.2124285) on $1^{\text {th }}$ December 2018 with the complaints of Reduced sleep since 6months which is associated with headache, episodes of giddiness, indigestion and generalized body ache, for all these complaints he consulted nearby doctor they advised CT brain all are within normal limit given Tab.Anxit 0.5mg 0-0-1 after food took this medicine more than 5yrs by these medication pt. didn't get complete relief later consulted to Kayachikitsa O.P.D Of S.S.Ayurvedic Medical College \& Hospital, Haveri, Karnataka.

PAST HISTORY: Patient is not having history of any chronic illness like DM/HTN and Thyroid disorders.

ON EXAMINATION: General examination

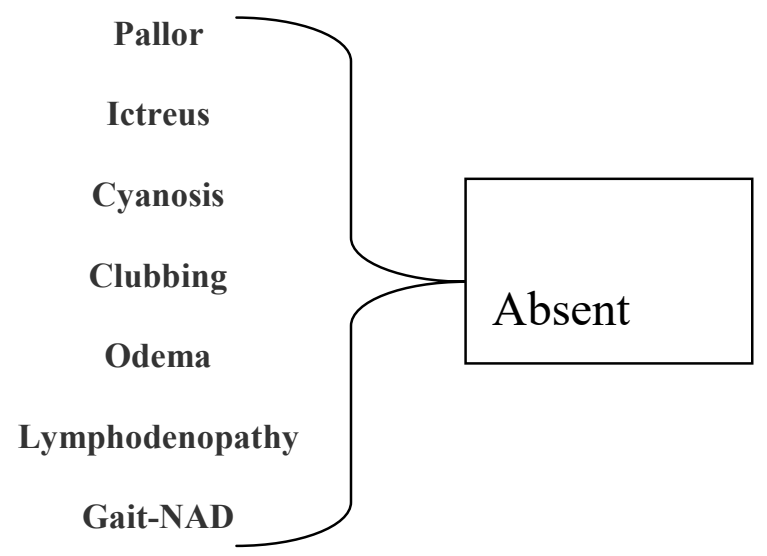

Height-5.2"

Weight-52kgs 
Vital signs: Temp. $98.6^{0 \mathrm{~F}}$

\author{
Pulse- $82 / \mathrm{min}$ \\ Respiratoryrate-20cycles/min \\ Bp-140/80 $\mathrm{mm}$ of $\mathrm{Hg}$
}

\section{MATERIALS AND METHODS}

\section{Source of data:}

- A diagnosed case of Nidranasha is selected from OPD of S.S.Ayurveda Medical College \& Hospital Kayachikitsa OPD, Haveri-

\section{Method of collection of data:}

- A special proforma is prepared with details of history taking, Physical and Psychological signs, Symptoms as mentioned in Ayurvedic classics and Allied sciences. The parameters of signs, symptoms is scored based on standard methods and analysed before and after treatment.

Karnataka.

ASSESSMENT OF SYMPTOMS BEFORE AND AFTER TREATMENT

\begin{tabular}{|c|c|c|c|c|}
\hline S. No & Nidranashalakshana & BT & AT & Difference \\
\hline $\mathbf{1}$ & Shirashoola(Headache) & $\mathbf{3}$ & $\mathbf{2}$ & $\mathbf{1}$ \\
\hline $\mathbf{2}$ & Angdaamarda\&Angasad(Malaise) & $\mathbf{3}$ & $\mathbf{2}$ & $\mathbf{1}$ \\
\hline $\mathbf{3}$ & Ajirna\&Agnimandya(Indigestion) & $\mathbf{2}$ & $\mathbf{0}$ & $\mathbf{0}$ \\
\hline $\mathbf{4}$ & Tandra(Drowsiness) & $\mathbf{0}$ & $\mathbf{0}$ & $\mathbf{0}$ \\
\hline $\mathbf{5}$ & Malabadhata(Constipation) & $\mathbf{0}$ & $\mathbf{0}$ & $\mathbf{0}$ \\
\hline $\mathbf{6}$ & Klama(Inertness) & $\mathbf{0}$ & $\mathbf{0}$ & $\mathbf{0}$ \\
\hline $\mathbf{8}$ & Arati(Fatigue) & $\mathbf{0}$ & $\mathbf{0}$ & $\mathbf{0}$ \\
\hline $\mathbf{9}$ & Manodourbalya & $\mathbf{0}$ & $\mathbf{0}$ & $\mathbf{0}$ \\
\hline $\mathbf{1 0}$ & Smritidourbalya & $\mathbf{0}$ & $\mathbf{0}$ & $\mathbf{0}$ \\
\hline $\mathbf{1 2}$ & Indriyakarmahani & $\mathbf{0}$ & $\mathbf{0}$ & $\mathbf{0}$ \\
& Dhatukshaya & & & $\mathbf{0}$ \\
\hline
\end{tabular}

INSOMNIA SCREENING QUESTIONNARE

\begin{tabular}{|c|c|c|c|c|}
\hline \multirow{2}{*}{ S. No } & Questions & \multicolumn{3}{c|}{ Score } \\
\cline { 3 - 5 } & & BT & AT & Difference \\
\hline 1 & Do you have trouble falling a sleep & 2 & 2 & $\mathbf{0}$ \\
\hline 2 & Do you have trouble staying a sleep & 3 & 2 & 1 \\
\hline 3 & Do you have wakeup un-refreshed & 2 & 1 & $\mathbf{1}$ \\
\hline 4 & Do you take anything to help u sleep & $\mathbf{0}$ & $\mathbf{0}$ & $\mathbf{0}$ \\
\hline $\mathbf{5}$ & Do you use alcohol to help you sleep & $\mathbf{0}$ & $\mathbf{0}$ & $\mathbf{0}$ \\
\hline $\mathbf{6}$ & $\begin{array}{c}\text { Do you have any medical condition that } \\
\text { disrupts your sleep }\end{array}$ & $\mathbf{0}$ & $\mathbf{0}$ & $\mathbf{0}$ \\
& $\quad$ & & & \\
\hline
\end{tabular}

Treatment protocol:

\begin{tabular}{|c|c|}
\hline $1^{\text {st }}$ PHASE(01-12-2018 to 08-12-2018) & $2^{\text {nd }}$ PHASE(09-12-2018 to 10-12-2018) \\
\hline $\begin{array}{l}\text { 1. Saraswatharista } 15 \mathrm{ml}-0-15 \mathrm{ml} \text { After food 1- } \\
0-1 \text { Before food }\end{array}$ & 1.Saraswatharista $15 \mathrm{ml}-0-15 \mathrm{ml}$ After food \\
\hline 2.Tab.Medhya vati 1-0-1 After food & $\begin{array}{l}\text { 2.Tab.Kamadugharasa with mukta } \\
\text { 1-0-1 Before food }\end{array}$ \\
\hline 3.Ksheerabala taila for Sarvanga abhyanga & 3.Ksheerabala taila for Abhyanga \\
\hline
\end{tabular}




\section{DISCUSSION}

Acc. To ayurveda understanding of vyadhi is mainly based on Laxana, Udbhavasthana and Adhisthana considering this acc. To Sushruta ${ }^{4}$ vyadhi is mainly classified into two types i.e. Shareera and Manoadhisthana. At present because of stress and changes in lifestyle many people suffering from minor to major psychiatric disorder. For disorders like Nidranasha (Insomnia) many classical herbomineral preparations are explained ,among these many preparations are used based on the involvement of Dosha, Dushya, Desha, Kala, Agni etc, Here an case presented with Dushti of Vata-Pitta and Manas hence the selection of the drugs as mentioned above. Rationality behind these drugs Saraswatharista ${ }^{5}$ is mainly having Bramhi panchanga as main ingradient which is having the property of Rasayana and chittasantosha. Medhya $\operatorname{vati}^{6}$ is Shankapushpi, Bramhi, Guduchi, Jatamamsi which are having medhya, Sanjyaprabhodana and Nidrajana properities which are very much useful to calm the mind of the individual. Kamadugharasa ${ }^{7}$ is mainly having Mukta bhasma, muktasukti bhasma, shanka, pravala and varatika bhasma which mainly acts on manovikara and pittahara, Ksheera bala taila is mainly having Goksheera, tilataila and bala which mainly acts as
Vatashamaka $^{8}$. Hence patient needs the combination of different formulations in cases of Nidranasha and even other psychiatric disorder too.

\section{CONCLUSION}

In this case study justifies the successful management of Nidranasha through simple, cost effective and easily available formulations. By this case study, we can conclude that in all cases of Nidranasha (Insomnia) if patient seeks Ayurveda treatment as early as possible the percentage of recovery is more. And we can prevent the drug dependency and adverse effect of Benzodiazepines and sedatives. As this is a single case study so it's very difficult to conclude the effect of Ayurvedic treatment, but along with shamana medicine it's very essential to plan panchakarma as the main treatment. To treat more effectively the combination of Panchakarma and shamana medications is very much essential; hence considering the dosha, dusha and avastha of the vyadhi, one can adopt the suitable treatment for the better result. But this case study might be considered as base for future research protocol on the management of Nidranasha through the combined effect of Panchakarma and Shamanoushadi. 


\section{REFERENCES}

1. Agnivesha, Carakasamhita Ayurveda deepika by cakrapani Datta edited by vaidyajadavajitrikamji acharya chaukhambha prakashan edition 2009 sutrasthana chapter no.11 verse 34 page no. 74pp 738

2. https://www.wikipedia.org/

3. Agnivesha, Carakasamhita Ayurveda deepika by cakrapanidatta edited by vaidyajadavajitrikamji acharya chaukhambha prakashan edition 2009 sutrasthana chapter no.21 verse 35 page no. 118 pp 738

4. Sushruta samhitanibandhasangraha by dhalhana edited by vaidyajadavajitrikamji acharya chaukhambha sanskrit sansthan edition -2012 sutrasthana chapter no.1 verse no.24 (3) page no.6pp 824

5. Bhishajya Ratnavalli by Kavirajshri Govind das sen edited by Prof. Siddhinandan mishra chaukhambha surbharati prakashan edition-2011 rasayanarogadhikara chapter no.
73 verse 148-171 page no.11201121 pp 1196

6. BhishajyaRatnavalli by Kavirajshrigovind das sen edited by Prof. Siddhinandan Mishra chaukhambha surbharati prakashan edition-2011 rogadhikara chapter no. 73 verse 148-171 page no.1120-1121 pp 1196

7. BhishajyaRatnavalli by Kavirajshrigovind das sen edited by Prof. Siddhinandan mishra chaukhambha surbharati prakashan edition-2011 amlapittarogadhikara chapter no. 73 verse 148-171 page no.11201121 pp 1196

8. Agnivesha, Carakasamhita ayurvedadeepika by cakrapanidatta edited by vaidyajadavajitrikamji acharya chaukhambha prakashan edition2009 Vatavyadhirogadhikara 28chapter no. verse 154-156 page no.626 pp 738 